\title{
KONSULTACJE OBLIGATORYJNE I FAKULTATYWNE W USTAWIE O PLANOWANIU I ZAGOSPODAROWANIU PRZESTRZENNYM A ZAKRES USPOLECZNIENIA PROCESÓW PLANOWANIA PRZESTRZENNEGO
}

\section{WPROWADZENIE}

Zagadnienie udziału społeczeństwa $\mathrm{w}$ zarządzaniu sprawami publicznym jest współcześnie coraz ważniejszym elementem dyskursu prawniczego. Świadczy o tym wykształcenie się odrębnej terminologii, mianowicie pojęć „partycypacja społeczna”, „konsultacje społeczne”, czy „dyskusja publiczna”, które stały się elementem języka prawnego ${ }^{1}$; nadto zauważa się coraz większe zainteresowanie ta problematyka przedstawicieli nauki prawa administracyjnego ${ }^{2}$. Jednym z nich jest D. R. Kijowski, który partycypację obywatelską (społeczna) określa jako zjawisko polegające na uczestniczeniu społeczności mieszkańców danej miejscowości, gminy, powiatu, regionu, a nawet państwa, w identyfikacji i rozwiązywaniu wspólnych potrzeb, problemów³. Co istotne, współcześnie aktywność wspólnot lokalnych przy realizacji zadań publicznych postrzegana jest coraz częściej nie jako wyjątek, ale zasada. Przejawem inicjatyw wykorzystujących potencjał tkwiący w społeczeństwie są ostatnio bardzo

${ }^{1}$ Np. art. 6 ust. 2 ustawy z 16 września 2011 r. o współpracy rozwojowej (Dz. U. Nr 243, poz. 1386 ze zm.) stanowi, że: ,w celu przeprowadzenia konsultacji społecznych projekt Programu udostępnia się w Biuletynie Informacji Publicznej urzędu obsługującego ministra właściwego do spraw zagranicznych", a art. 5 ust. 4 pkt 5 ustawy z 6 lipca 2001 r. o ustanowieniu programu wieloletniego „Program dla Odry - 2006” (Dz. U. Nr 98, poz. 1067) stwierdza, że do zadań Komitetu Sterującego należy m.in. prowadzenie konsultacji społecznych przy realizacji Programu oraz poszczególnych inwestycji przewidzianych w Programie.

${ }^{2}$ Np. D. R. Kijowski, Partycypacja obywatelska $w$ samorzadowych procesach decyzyjnych zagadnienia ogólne, „Samorząd Terytorialny” 2010, nr 1-2, s. 9-21; P. J. Suwaj, Udział społeczeństwa $w$ decydowaniu publicznym - oblicza partycypacji społecznej $w$ polityce publicznej $w$ zakresie inwestycji drogowych, „Samorząd Terytorialny” 2010, nr 1-2, s. 59 i n.; K. Ostaszewski, Partycypacja spoteczna $w$ procesie podejmowania rozstrzygnięć $w$ administracji publicznej, Lublin 2013; nadto warto wskazać konferencję naukową zorganizowaną przez Katedrę Prawa Samorządu Terytorialnego Wydziału Prawa i Administracji Uniwersytetu Ślaskiego w Katowicach „Partycypacja społeczna w samorządzie terytorialnym" (14-15 marca 2013 r.).

${ }^{3}$ D. R. Kijowski, op. cit., s. 9; zob. także I. Niżnk-Dobosz, Partycypacja jako pojęcie i instytucja demokratycznego państwa prawnego i prawa administracyjnego, w: B. Dolnicki (red.), Partycypacja spoteczna w samorzadzie terytorialnym, 2014, Lex, nr 186235. 
popularny budżet obywatelski bądź inicjatywa lokalna ${ }^{4}$. Podkreślić należy, że działania te zasługują na tym większą uwagę, gdyż często są elementem konsultacji dobrowolnych, co oznacza, że ich przeprowadzenie zależy wyłącznie od woli organu, nie jest wymagane przepisami prawa ${ }^{5}$.

Celem niniejszego opracowania jest przede wszystkim analiza przepisów ustawy z 27 marca 2003 r. o planowaniu i zagospodarowaniu przestrzennym ${ }^{6}$, stanowiących podstawę uczestniczenia w procesie planowania przestrzennego poprzez instytucję konsultacji obligatoryjnych i fakultatywnych. Z punktu widzenia uspołecznienia procesów planistycznych z pewnością spory potencjał tkwi w konsultacjach fakultatywnych. Wynika to przede wszystkim $\mathrm{z}$ tego, że przyznana samorządowi terytorialnemu samodzielność, mająca podstawy w konstytucyjnej zasadzie decentralizacji i pomocniczości, umożliwia wykazanie się organom gminy, przede wszystkim wójtowi (burmistrzowi, prezydentowi) kreatywnością i inicjatywą w zakresie włączania społeczności lokalnej w proces współdecydowania czy dialogu. Jedna z takich inicjatyw jest chociażby planowanie partycypacyjne (community planning), które z powodzeniem było już stosowane zarówno za granica ${ }^{7}$, jak i w Polsce ${ }^{8}$. Stąd też w części opracowania dotyczącej konsultacjach fakultatywnych wskazane zostaną różne formy, za pomoca których może nastapić upodmiotowienie społeczności lokalnych w procesie planowania. Natomiast w przypadku konsultacji obligatoryjnych nacisk zostanie położny na analizę przepisów prawnych, gdyż uchybienie wymogom formalnym może prowadzić do uchylenia studium uwarunkowań i kierunków zagospodarowania przestrzennego gminy (dalej: studium), czy miejscowych planów zagospodarowania przestrzennego (dalej: miejscowych planów).

\section{OBLIGATORYJNE FORMY KONSULTACJI SPOLECZNYCH W USTAWIE O PLANOWANIU}

Obligatoryjne zasięgnięcie opinii społeczności lokalnych w procedurze planistycznej następuje za pomocą następujących instytucji prawnych: wniosków, dyskusji publicznej oraz uwag.

Regulacja prawna dotycząca wniosków i skarg w ustawie o planowaniu jest zdecydowanie lakoniczna. Zasadniczo prawodawca stwierdza jedynie, że istnieje możliwość składania ich w określonych ramach czasowych, i nakazuje

${ }^{4}$ Zob. rodział II ustawy z 24 kwietnia 2003 r. o działalności pożytku publicznego i wolontariacie, t.jedn.: Dz. U. 2014, poz. 1118 ze zm.

${ }^{5}$ Więcej na temat zob. np. w: E. Olejniczak-Szałowska, Konsultacje we wspólnocie samorzqdowej, „Samorząd Terytorialny” 1997, nr 1-2.

${ }_{6}^{6}$ T.jedn.: Dz. U. 2012, Nr 647 ze zm. (dalej jako: ustawa o planowaniu).

7 Np. przy projektowaniu rozwoju miejscowości Aylesham w Wielkiej Brytanii, zob. http:// www.communityplanning.net/casestudies/casestudy001.php (dostęp: 5.11.2014).

${ }^{8}$ Zob. Top Down/Bottom Up 11.Kongres PlaNet Warszawa 2007 Partycypacja Spoteczna w kształtowaniu przestrzeni miejskiej w rewitalizacji Pragi Pótnoc i Żoliborza, red. W. Biała, Warszawa 2007. 
organom gminy ustosunkować się do nich. Nieco więcej miejsca, jako donioślejszym, poświęca tym drugim. Brak jakichkolwiek ograniczeń podmiotowych i przedmiotowych powoduje, że konsultacje społeczne w tej ustawie należy rozumieć jak najszerzej. Tym samym mogą je składać osoby fizyczne, prawne, w szczególności organizacje pozarządowe (np. stowarzyszenia i fundacje, jednostki nieposiadające osobowości prawnej czy grupy osób), a nawet władze publiczne, tzn. inne niż organy gminy uchwalającej plan ${ }^{9}$. Co istotne, żaden przepis nie wskazuje, że wnioskodawcy muszą być członkami społeczności lokalnych, niemniej co do zasady zainteresowanymi są w przeważajacej mierze mieszkańcy wspólnoty. Nie mają takich korzeni niektórzy przyszli inwestorzy, którzy mając określone plany względem konkretnych gruntów, wskazują na korzystny dla siebie sposób przeznaczenia lub realizację określonych funkcji. Wydaje się, że atrakcyjne grunty inwestycyjne ze swej istoty czynia proces uchwalania miejscowych planów ponadlokalnym, a niekiedy wręcz międzynarodowym. Tym samym ustawa przyjęła otwartą formułę składania wniosków i uwag $^{10}$.

Zarówno wnioski, jak i uwagi mają charakter wypowiedzi opiniujacych, niewiążących dla ostatecznych ustaleń. T. Bąkowski wskazuje na podobieństwo wniosków w ustawie o planowaniu i wniosków formułowanych na zasadach i w trybie Kodeksu postępowania administracyjnego ${ }^{11}$. Sa one wyrazem społecznej inicjatywy, a ich przedmiotem są postulaty bądź propozycje. Charakteryzują się przy tym „względną skutecznością” rozumianą jako obowiązek ustosunkowania się do nich organu, a nie załatwienia ich pozytywnie ${ }^{12}$. Doniosłość przejawia się jednak w tym, że sa one obligatoryjnym elementem konsultacji społecznych i ich pominięcie jest istotnym naruszeniem trybu sporządzania aktów planistycznych, co skutkuje stwierdzeniem ich nieważności. Co więcej, to właśnie od złożenia propozycji konkretnych rozwiązań rozpoczynają się prace nad studium i miejscowymi planami - tzn. ogłoszeniu o przystapieniu do sporządzania towarzyszy określenie formy, miejsca i terminu składania wniosków. Co istotne, zarządzenie organu w sprawie ich rozpatrzenia stanowi informację publiczną ${ }^{13}$.

W sprawie realizacji rzeczywistego zakresu partycypacji społecznej i tym samym za szczególnie doniosłe należy uznać orzeczenie NSA z 4 listopada 1999 r. ${ }^{14}$, w którym poddano analizie zagadnienie czasu wyłożenia projektu miejscowego planu do publicznego wglądu, które zachowuje aktualność także w stosunku do procedury uchwalania studium. Mianowicie 21-dniowy termin winien być obliczany przez odniesienie się do „dni roboczych” urzę-

9 Podobnie I. Zachariasz, Komentarz do art. 11 ustawy o planowaniu $i$ zagospodarowaniu przestrzennym, w: H. Izdebski, I. Zachariasz, Ustawa o planowaniu i zagospodarowaniu przestrzennym. Komentarz, Lex 143782.

${ }^{10}$ Art. 11 pkt 1 i pkt 11 oraz art. 17 pkt 1 i 11 ustawy o planowaniu.

11 Ustaw z dnia 14 czerwca 1960 r. - Kodeks postępowania administracyjnego, t.jedn.: Dz. U. 2013, poz. 267 ze zm.

12 T. Bąowski, Komentarz do art. 11 ustawy o planowaniu $i$ zagospodarowaniu przestrzennym, w: Ustawa o planowaniu i zagospodarowaniu przestrzennym. Komentarz, Kraków 2004.

13 IV SAB/Wr 62/09, Lex, nr 555549.

14 IV SA 1683/98, Lex, nr 48260. 
du, a więc takich dni, w których zainteresowani mogą zapoznać się z założeniami i treścią projektów, a nie w dni wolne od pracy. Słusznie orzekł bowiem NSA, że wskazany termin ma charakter szczególny, a jego istota jest stworzenie możliwości obywatelom zapoznania się z treścią dokumentu. Nadto należy zauważyć, że są takie okresy w ciagu roku, w których wyłożenia takiego należałoby unikać. Wprawdzie nie ma przepisu, który by takiej praktyki zakazywał, ale za niezgodne z zasadami dobrej administracji należałoby uznać wyłożenie projektów dokumentów planistycznych w takim czasie, w którym faktycznie ogranicza się możliwość wypowiedzenia się zainteresowanym. Aby ustrzec się przed wskazanymi zarzutami, gminy powinny udostępniać na swojej oficjalnej stronie dokumenty związane z uchwalanym studium i planów, w tym projekt wraz z licznymi wizualizacjami. Sprawi to, że rzeczywisty wgląd w przypadku dostępu do Internetu trwa ponad miesiac. Na tenże aspekt wskazuje M. Szewczyk, którego zdaniem dostęp 7 dni w tygodniu do projektów relatywizuje liczenie 21-dniowego terminu wyłącznie przez odniesienie się do „dni roboczych”" ${ }^{15}$. Niezależenie od powyższego nie można zapominać o tym, że są to obszerne, skomplikowane, specjalistyczne dokumenty, stąd też zaletą udostępnienia ich w urzędzie gminy jest możliwość porady fachowej w zakresie objaśniania terminów, instytucji i przyjętych rozwiązań. Na koniec należy zauważyć, że dopiero od momentu wyłożenia projektu do publicznego wglądu można składać uwagi. Tym samym niefrasobliwość organu, a konkretnie umocowanych przez niego urzędników, przy wyznaczaniu czasu dostępu wglądu ogranicza de facto zakres konsultacji społecznych, co może być odebrane jako działania celowe. Trudno przy tym uznać prawo wglądu za przejaw partycypacji, która jest procesem, polega na uczestniczeniu.

Zakres uspołecznienia w założeniu wzmacnia instytucja dyskusji publicznej, występujacca pomiędzy składaniem wniosków i uwag, o której tylko wspominaja art. 11 pkt $10 \mathrm{i}$ art. 17 pkt 9 ustawy o planowaniu. Mimo że w aktach wykonawczych do ustawy o planowaniu pojawiają się protokoły z jej przeprowadzenia, to żaden przepis nie przybliża jej istoty i trudno mówić, że ma ona jakaśs określona formułę. Taka regulacja pozostawia wiele swobody wójtowi, przy tym nie można zapominać, że jest obligatoryjnym elementem uchwalania planu. Z braku definicji legalnej w ustawie o planowaniu należy wnioskować, że określenie to zostało użyte przez prawodawcę zgodnie z jego poprawnym, podstawowym i powszechnie przyjetym znaczeniem ${ }^{16}$. Chodzi zatem o rozumienie powszechnie przyjęte w języku polskim. Przykładowo w jednej ze słownikowych definicji przez dyskusję rozumie się ustna lub pisemną wymianę zdań na jakiś temat, majaccą prowadzić do wspólnych wniosków ${ }^{17}$. Za nieco innym pojmowaniem opowiedział się NSA w orzeczeniu z 20 czerwca 2006 r., podnosząc, że: istotą,dyskusji publicznej” jest to, iż pod-

15 M. Kruś, Z. Leoński, M. Szewczyk, Prawo zagospodarowania przestrzeni, Warszawa 2012, s. 134 .

${ }_{16}$ G. Wierczyński, Komentarz do zat. \$146 rozporzadzenia w sprawie „Zasad techniki prawodawczej”, pkt 7, w: Redagowanie i ogłaszanie aktów normatywnych. Komentarz, 2009, Lex 55527.

17 Stownik języka polskiego, PWN, http://sjp.pwn.pl/szukaj/dyskusja (dostęp: 15.06.2014). 
mioty w niej uczestniczące wypowiadają swoje opinie co do rozwiązań przyjętych w projekcie studium. Cechą „dyskusji publicznej” jest zatem zamiar wysondowania opinii (poglądów, stanowiska) określonych grup społecznych (wspólnoty samorządowej lub zainteresowanych środowisk). Dyskusja ta ma charakter opiniodawczy, a więc jej wynik nie jest wiążący dla organów gminy ${ }^{18}$. W tym znaczeniu służy wymianie poglądów, a nie uzgodnieniu wspólnego stanowiska, choć jej ważnym elementem powinno być ustosunkowanie się do cudzego poglądu. Wydaje się, że zaprezentowane rozumienie dyskusji jest właściwe. Odmienne pojmowanie pozostawałoby w opozycji do wykładni systemowej i celowościowej, gdyż żaden przepis ustawy o planowaniu nie przyzwala na wiążące wpłynięcie konsultacji na ostatecznie przyjęte rozwiązania. Potwierdza to w szczególności art. 7 ustawy o planowaniu, który wskazuje na opiniodawczy, a nie konsensualny, charakter wniosków i uwag. Tym samym debata publiczna jest środkiem umożliwiajacym raczej tylko wypowiedzenie się społeczności lokalnych w kwestii przyszłych rozwiązań planistycznych. Wydaje się, że jedynym skutecznym sposobem wzruszenia przyjętych, niewiążących rezultatów jest kwestia formalna, związana z niewłaściwym poinformowaniem o jej terminie i tym samym uniemożliwieniem wypowiedzenia się zainteresowanym.

Najsilniejszym środkiem prawnym oddziaływania na projekty aktów planistycznych są uwagi, które - odmiennie niż wnioski - dotyczą już istniejących dokumentów (mogą dotyczyć części tekstowej lub graficznej). Można je złożyć zarówno do studium, jak i do miejscowego planu. W przypadku tego drugiego co do ich istoty, zgodnie z art. 18 ust. 1 ustawy o planowaniu, należy zakwestionowanie ustaleń przyjętych w projekcie, jednak nie stanowia swoistego środka prawnego zaskarżenia ustaleń projektu planu ${ }^{19}$. Sa środkiem prewencyjnym, umożliwiającym przedstawienie stanowiska wskazującego potencjalne pola naruszenia w przyszłości interesu prawnego lub uprawnienia $^{20}$. Nie powinny, abstrahując od dotychczasowego stanu projektu, proponować całkowicie nowego ładu planistycznego. Wydaje się, że nie będzie to właściwa forma wyrażenia aprobaty przyjętych rozwiązań, choć zdarzają się poglądy odrębne ${ }^{21}$. Muszą być złożone w formie pisemnej (także elektronicznej opatrzonej bezpiecznym podpisem), natomiast nie ma znaczenia powód ich wniesienia. Słusznie zauważa przy tym M. Szewczyk, że moga przybrać dwojaki charakter. Z jednej strony, jeśli nie będą dotyczyć indywidualnego i konkretnego interesu, przybiora charakter actio popularis, z drugiej jeśli spełnią wspomnianą przesłankę, będą korzystały z ochrony na zasadach określonych w art. 101 ustawy z 8 marca 1990 r. o samorządzie gminnym ${ }^{22}$. Ranga uwag składanych do miejscowych planów jest przy tym zdecydowanie większa niż w przypadku uwag do studium, a zasadniczą kwestię stanowią

18 II OSK 277/06, Lex, nr 266913, orzeczenia.nsa.gov.pl.

19 Wyrok NSA z 9 maja 2008 r., II OSK 45/08, Lex, nr 497582.

${ }^{20}$ Wyrok WSA w Gdańsku z 19 grudnia 2007 r., II SA/Gd 576/07, Lex, nr 390849.

21 Zob. wyrok NSA z 31 sierpnia 2012 r., II OSK 1300/12, orzeczenia.nsa.gov.pl.

22 T.jedn.: Dz. U. 2013, poz. 594 ze zm.; zob. M. Szewczyk, M. Kruś, op. cit., s. 155; także wyrok NSA z 20 czerwca 2008 r., II OSK 1932/07, Lex, nr 490129. 
konsekwencje prawne wynikajace $\mathrm{z}$ ich uwzględnienia. Mianowicie zgodnie z art. 19 ustawy o planowaniu, jeżeli rada gminy stwierdzi konieczność dokonania zmian w przedstawionym do uchwalenia projekcie planu miejscowego w wyniku uwzględnienia uwag do projektu planu, to czynności, o których mowa w art. 17 ustawy o planowaniu, ponawia się w zakresie niezbędnym do dokonania tych zmian. Oznacza to, że uwzględnienie uwag skutkuje ponowieniem czynności planistycznych. Pojawia się jednak pytanie, czy dotyczy to wszystkich punktów z art. 17 ustawy o planowaniu, czy też niektórych z nich. Przedstawiciele nauki prawa administracyjnego zgodnie ograniczają zakres tych czynności. Na przykład I. Zachariasz podnosi, że o zakresie ponowienia procedury, zwłaszcza etapów określonych w art. 17 pkt 9, 11 i 12 ustawy o planowaniu, decydować powinna z jednej strony analiza zmian zgłoszonych przez radę, z drugiej - funkcja uwag, która jest ujawnianie interesów i rozwiąywanie potencjalnych konfliktów w zakresie zagospodarowania przestrzennego na etapie sporządzania planu miejscowego; ocena w tym zakresie należy do organu wykonawczego gminy ${ }^{23}$. Słusznie zauważa przy tym Z. Niewiadomski, że obowiązkiem tym nie są objęte czynności określone w art. 17 pkt 1-3 ustawy o planowaniu, a także w pkt 6 , o ile nie zajdzie potrzeba nowych opinii i uzgodnień. Nadto ponownej ocenie może podlegać prognoza oddziaływania na środowisko oraz prognoza skutków finansowych planu ${ }^{24}$. Przy tym powtórne postępowanie powinno ograniczać się jedynie do tego fragmentu (fragmentów) terenu objętego pracami planistycznymi, do którego odnosza się przedmiotowe zmiany ${ }^{25}$.

Z powyższego wynika, że zmiany daleko idące muszą być ponownie przedmiotem drugiego etapu konsultacji społecznych ${ }^{26}$. Ponieważ uwzględnienie uwag powoduje potrzebę ponowienia procedury planistycznej, wymaga więc właściwego określenia czynności, które należy powtórzyć. Pomyłka w tej kwestii będzie bowiem przedmiotem oceny organu nadzoru i wpływała na byt prawny miejscowego planu. Pomocne $\mathrm{w}$ tej kwestii sa rozważania NSA z 5 października 2011 r. Sąd podniósł, że jeżeli uwagi mają charakter indywidualny, sa zgłaszane w odniesieniu do poszczególnych działek, to jako takie moga być uwzględniane przez wójta w trybie art. 17 pkt 13 ustawy o planowaniu, tj. bez obowiązku ponowienia procedury planistycznej. Z kolei wprowadzanie arbitralnie przez wójta zmian o charakterze ogólniejszym, w sytuacji konfliktu interesów różnych grup właścicieli działek położonych na obszarze objętym zmianami, uwzględniające interesy jednych, a naruszające innych właścicieli, powoduje, że ci, którzy są w opozycji do zmian, tracą możliwość

${ }^{23}$ I. Zachariasz, Komentarz do art. 19 ustawy o planowaniu i zagospodarowaniu przestrzennym, w: H. Izdebski, I. Zachariasz, op. cit.

${ }^{24}$ Z. Niewiadomski (red.), Planowanie $i$ zagospodarowanie. Komentarz, Warszawa 2011, s. $199-200$.

${ }_{25}$ T. Bąkowski, Komentarz do art. 19 ustawy o planowaniu $i$ zagospodarowaniu przestrzennym w: Ustawa o planowaniu i zagospodarowaniu przestrzennym. Komentarz, Kraków 2004; podobnie W. Jakimowicz, Konstrukcja i istota wolnościowego prawa zabudowy, „Samorząd Terytorialny" $2005, \mathrm{nr} 6$.

${ }_{26}$ Zob. wyrok NSA z 9 października 2007 r., II OSK 965/07, Lex, nr 366753. 
ich kwestionowania $\mathrm{w}$ formie uwag do projektu, rozpatrywanych przez radę gminy na sesji uchwalajaccej plan ${ }^{27}$.

Natomiast brak odpowiednika art. 19 ustawy o planowaniu w stosunku do studium skłonił Wojewódzki Sąd Administracyjny w Olsztynie w wyroku z 5 kwietnia 2012 r. do przyjęcia tezy, że zmiana projektu studium przez radę gminy w wyniku uwzględnienia uwagi dotyczacej tego projektu nie wywołuje potrzeby ponowienia czynności wymienionych w art. 11 ustawy o planowaniu $^{28}$. Argumentował to także wewnętrznym charakterem studium. Stanowisko to nie jest jednak powszechnie przyjmowane, a w doktrynie coraz częściej zwraca się uwagę na potrzebę ponownego przeprowadzenia części procedury, np. uzgodnień organów współdziałających ${ }^{29}$. Jako uzasadnienie wskazuje się także ogólne zasady Kodeksu postępowania administracyjnego czy zasadę prawa do dobrej administracji ${ }^{30}$.

W orzecznictwie zauważa się również inna, doniosłą cechę partycypacji społecznej. Mianowicie brak aktywności uprawnionego, najczęściej właściciela, podczas długotrwałej i szeroko pojętej procedury planistycznej (składanie wniosków do projektu planu lub na etapie poprzedzającym, uczestnictwo w debacie publicznej i innych formach udostępniania wiedzy o projekcie, np. zebrania sołeckie, a także złożenie uwag) może być postrzegany jak rezygnacja z tych uprawnień. Argumentem przemawiajacym za taka interpretacja jest fakt, że organy gminy nie mogą domniemywać zamierzeń właścicieli. Tym bardziej gdy uchwalany plan jest zgodny z postanowieniami studium, obowiązującego od wielu lat ${ }^{31}$, i trudno wtedy skutecznie zarzucać organom gminy przekroczenie granic władztwa planistycznego. Jednakże ustawa o planowaniu w żadnym miejscu nie wprowadza obowiązku uczestnictwa w konsultacjach społecznych, stąd wyprowadzanie negatywnych skutków z takiego zaniechania, jako jedynej przesłanki odrzucenia skargi, jest z pewnościa niedopuszczalne. Niemniej jednak $\mathrm{w}$ zaistniałym stanie faktycznym nieuczestniczenie $\mathrm{w}$ konsultacjach społecznych stanowiło jedynie potwierdzenie braku przekroczenia granic władztwa planistycznego. I tylko w takim kontekście można postrzegać bierna postawę jednostki na jej niekorzyść. Niemniej argumentacja o braku aktywności jednostki w konsultacjach społecznych podnoszona jest także w późniejszych orzeczeniach ${ }^{32}$, co budzi pewien niepokój, szczególnie w aspekcie instytucji następstwa prawnego. Zgodzić się bowiem należy z I. Zachariaszem, że nieskorzystanie z prawa do wnoszenia uwag przed uchwaleniem planu nie

${ }^{27}$ II OSK 1435/11, Lex, nr 1070332; zob. także wyrok NSA z 8 grudnia 2010 r., II OSK 1948/10, Lex, nr 746855 .

${ }^{28}$ II SA/Ol 150/12, Lex, nr 1145831; por. wyrok WSA w Krakowie z 20 grudnia 2010 r., II SA/Kr 934/10, Lex, nr 753701. Zob. także Z. Niewiadomski, op. cit., s. 129.

${ }^{29}$ Wyrok NSA z 9 grudnia 2009 r., II OSK 1537/09, Lex, nr 580922.

30 Zob. A. Brzezińska-Rawa, Uwagi do projektu studium uwarunkowań i kierunków zagospodarowania przestrzennego gminy, pkt 5, w: B. Dolnicki (red.), op. cit.

${ }^{31}$ Wyrok NSA z 8 kwietnia 2010 r., II OSK 123/10; wielokrotnie cytowany np. wyrok NSA z 19 kwietnia 2012 r., II OSK 509/12.

${ }^{32}$ Por. wyrok NSA z 8 listopada 2011 r., II OSK 1933/11, Lex, nr 1152101, czy wyrok NSA z 7 sierpnia 2012 r., II OSK 1231/12, Lex, nr 1379546. 
uniemożliwia późniejszego kwestionowania prawidłowości podjętej uchwały ${ }^{33}$. Natomiast zasadne jest stanowisko, że wniesienie przez określony podmiot uwag do projektu planu miejscowego w trybie art. 18 ustawy o planowaniu nie czyni z tego podmiotu w każdej sytuacji podmiotu legitymowanego do złożenia skargi na uchwałę w sprawie zmiany miejscowego planu ${ }^{34}$.

Na koniec warto podnieść jeszcze jedna, ważną kwestię, mianowicie możliwość zastępowania konsultacji społecznych referendum. Nie ulega watpliwości, że formami partycypacji społecznej są instrumenty demokracji bezpośredniej, w tym referendum. Zgoda istnieje co do tego, że nie można utożsamiać referendum z konsultacjami społecznymi. Wynika to przede wszystkim z tego, że celem referendum jest bezpośrednie podjęcie decyzji ${ }^{35}$, natomiast złożenie uwag i wniosków jedynie może wpłynąć na ostateczne rozstrzygnięcie, stąd też ich celem jest wyrażenie opinii. Tym samym niedozwolone jest uznanie dopuszczalności wniosku referendalnego odnoszącego się do formułowania założeń planistycznych. Sprzeciwiałoby się to obowiązujacym przepisom ustawy o planowaniu, które w szczegółowej procedurze, przyznając uprawnienie do rozstrzygania tej kwestii organowi uchwałodawczemu, gwarantują udział lokalnego społeczeństwa w ściśle określonych formach, wśród których nie wymienia się referendum lokalnego ${ }^{36}$. Powyższe rozważania wskazuja, że obecna regulacja w zakresie konsultacji fakultatywnych nie umożliwia realnego wpływu na proces planowania. Podkreśla to art. 7 ustawy o planowaniu, którego celem jest uprawnienie procesu uchwalania miejscowego planu i studium (niezaskarżalność do sądu administracyjnego składanych wniosków i uwag). Także w prezydenckim projekcie ustawy o współdziałaniu w samorządzie terytorialnym na rzecz rozwoju lokalnego i regionalnego oraz o zmianie niektórych ustaw $^{37}$ podstawowe brzmienie art. 7 ustawy o planowaniu nie uległo zmianie, co dowodzi braku woli zwiększenia obligatoryjnego zakresu partycypacji. Stąd ciężar ochrony interesu jednostki został przeniesiony na sądownictwo administracyjne. Nadto organ nie jest nawet zobowiązany do uzasadniania decyzji w zakresie nieuwzględniania zgłoszonych uwag. Z powyższego wynika, że zasadniczo miejscowa społeczność musi godzić się na narzucone rozwiązania. Natomiast organ ma możliwość przyjęcia rozstrzygnięcia ze świadomością istnienia ewentualnych, potencjalnych konfliktów indywidualnych i zbiorowych, jaki przyjmowany dokument może w przyszłości wywoływaćc ${ }^{38}$. Wydaje się, że jednym z głównych celów ustawy o planowaniu jest usprawnienie procedury planistycznej. W tym zakresie uspołecznienie konsultacji fakultatywnych wymaga zmian ustawodawczych. Niemniej podkreślić należy, że nie chodzi o to,

${ }^{33}$ I. Zachariasz, Komentarz do art. 18 ustawy o planowaniu i zagospodarowaniu przestrzennym, w: H. Izdebski, I. Zachariasz, op. cit.; zob. także wyrok WSA w Gdańsku z 28 stycznia 2009 r., II SA/Gd 564/08, Lex, nr 522481.

${ }^{34}$ Wyrok NSA z 20 czerwca 2008 r., II OSK 1932/07, Lex, nr 490129.

35 E. Olejniczak-Szałowska, op. cit., s. 108.

${ }^{36}$ Wyrok NSA z 20 marca 2014 r., II OSK 344/14, orzeczenia.nsa.gov.pl.

37 Sejm RP VII kadencji, druk nr 1699, art. 62 pkt 2, http://www.sejm.gov.pl/sejm7.nsf/PrzebiegProc.xsp?nr=1699 (dostęp: 12.11.2014).

38 D. Kijowski, op. cit., s. 18. 
by jednostki miały możliwość blokowania uchwalania miejscowych planów, ale by realnie uczestniczyły w ich sporządzaniu i wpływały na ich treść.

Natomiast w ramach uspołecznienia procesu planowania niewykorzystany potencjał tkwi w debacie publicznej. Za pomoca tego instrumentu można sięgnać do wielu wypracowanych już na świecie form partycypacji społecznej ${ }^{39}$. Niemniej jej krótki czas (21 dni) istotnie ogranicza możliwości działania. Przy tym ewentualne zmiany będą dotyczyły gotowego już projektu, stąd otwartym pozostaje pytanie, w jakim stopniu zgłoszone propozycje będą mogły różnić się od projektu pierwotnego i czy będą mogły ingerować w ogólną koncepcję. $\mathrm{Z}$ tych względów trudno sądzić, by mogły odegrać znaczącą rolę ${ }^{40}$.

\section{FAKULTATYWNE FORMY KONSULTACJI SPOLECZNYCH W USTAWIE O PLANOWANIU}

Zainicjowanie procesu uchwalania studium i miejscowych planów należy do organów gminy. Jedną z przesłanek (wielu z możliwych) przystapienia do tych działań jest rewizja wprowadzonych rozwiązań, gdyż z istoty swej planowanie przestrzenne to proces ustawiczny ${ }^{41}$. Obowiązek uaktualniania spoczywa wprost na wójcie, który zgodnie z art. 32 ust. 1 ustawy o planowaniu ma dokonywać m.in. analiz zmian w zagospodarowaniu przestrzennym gminy co najmniej raz na kadencję, czy opracowywać wieloletnie programy sporządzania miejscowych planów. Jednym z czynników wpływających na zainicjowanie procesu uchwalania lub zmiany są wnioski zainteresowanych (art. 32 ust. 1 ustawy o planowaniu in fine), które należy odróżnić od wniosków składanych w trakcie wszczętej formalnie procedury planistycznej. Wydaje się, że jest to pierwszy moment, w którym członkowie społeczności lokalnej mogą przedstawić swoje pomysły i tym samym wpłynąć na ład przestrzenny. Co więcej, ich rejestr prowadzić powinien organ wykonawczy gminy, a im większa liczba złożonych wniosków, tym większa szansa na podjęcie działań celem aktualizacji potrzeb.

Inną formą uspołecznienia procedury planistycznej jest „pośrednia”, nieobligatoryjna debata publiczna. Jest elementem niewładczego działania administracji publicznej, często o charakterze propagandowym, choć zasada jest prezentacja także innych stanowisk niż organów gminy, w tym radnych, lokal-

\footnotetext{
${ }^{39}$ Zob. np. P. Healey, Collaborative Planning Shaping Places in Fragmented Societies, UBC Press, Vancouver 2007; H. Sanoff, Community Participation Methods in Design and Planning, John Willey and Sons, New York-Chichester-Weinheim-Brisbane-Singapure-Toronto 2000; P. Lorens, Participatory Planning for Urban Regeneration - the Polish Experience, w: 14th International Conference on Urban Planning, Regional Development and Information Society-Strategies, Strategies, Concepts and Technologies for Planning the Urban Future, red. M. Schrenk et al., Sitges 2009.

${ }^{40}$ Zob. Ł. Damurski, Dyskusja (nie)publiczna. Problem dostęności dokumentów planistycznych na poziomie gminy, „Samorząd Terytorialny” 2014, nr 4; K. Rokicka, Konstrukcja dyskusji publicznej nad rozwiqzaniami przyjętymi $w$ projekcie studium uwarunkowań $i$ kierunków zagospodarowania przestrzennego oraz miejscowego planu zagospodarowania przestrzennego, w: B. Dolnicki (red.), op. cit.

${ }^{41}$ T. Bakowski, Komentarz do art. 32 ustawy o planowaniu $i$ zagospodarowaniu przestrzennym, w: Ustawa o planowaniu i zagospodarowaniu przestrzennym. Komentarz.
} 
nych organizacji pozarządowych i oczywiście osób fizycznych. Niekiedy przybiera postać dyskusji, której celem jest jednak przede wszystkim uświadomienie społeczności lokalnej o obranych kierunkach działań, rzadziej połączona jest z rzeczywistym wpływaniem na kształt aktów planistycznych. Mimo że charakter takich spotkań jest raczej informacyjny, to jednak jest to kolejna możliwość zaakcentowania stanowisk, przede wszystkim przez społeczności lokalne, czy wskazania oczywistych błędów.

Powyższa działalność jest ściśle połączona z innym elementem procesu planistycznego: aby dodatkowe, fakultatywne konsultacje społeczne miały wymiar rzetelnej dyskusji nad zaproponowanymi rozwiązaniami niezbędne jest zapewnienie dostępu do założeń planistycznych czy roboczych projektów. Mowa tu o innym, ważnym aspekcie - dostępie do informacji planistycznej, czyli takiej informacji publicznej, która dotyczy procesu budowania ładu przestrzennego. Obowiązek udostępnienia niektórych dokumentów planistycznych wynika wprost z ustawy o planowaniu, np. informacja o przystapieniu do sporzadzania studium i miejscowych planów czy ich projekty. Upubliczniać należałoby także inne dokumenty, np. rozstrzygnięcie w sprawie złożonych wniosków zgłoszonych na podstawie art. 11 pkt 1 i 17 pkt 1 ustawy o planowaniu, czy prognozę skutków finansowych uchwalanego miejscowego planu. W przypadku tych ostatnich dostępność najczęściej zależy od polityki informacyjnej przyjętej przez daną gminę. Współcześnie o wiele łatwiej spełnić ten postulat. Mianowicie na stronach internetowych, np. miejskich pracowni urbanistycznych, wystarczy udostępnić wskazane dokumenty, w tym wstępne wersje projektów, w szczególności tych powstałych na potrzeby nieobligatoryjnych, „pośrednich” konsultacji społecznych zwieńczonych debata publiczną. Jednym z zauważalnych, pozytywnych aspektów takiego wyłożenia jest możliwość wskazania błędów i niespójności, które szczególnie w przypadku studium mogły pojawić się na etapie planowania bądź założeń. Co istotne, kwestia możliwości wcześniejszego zapoznania się, w przypadku projektu studium, często z kilkuset stronicowym opracowaniem jest zagadnieniem o wiele poważniejszym. Przede wszystkim z racji swej obszerności możliwość realnego objęcia jego treści wymaga wielu dni. Po drugie, odkodowanie przyjętych rozwiązań, i tym samym ich zrozumienie, może być związane z potrzebą konsultacji ze specjalistami. Dopiero tak przygotowana jednostka może świadomie wypowiedzieć się na temat projektu i podjać ewentualne działania zmierzające do realizacji czy ochrony swoich interesów. Inną dobra praktyką jest odrębne informowanie rad dzielnic, które następnie w drodze uchwał ustosunkowują się do projektów.

Jednym z dokumentów jest prognoza skutków finansowych uchwalenia miejscowego planu, która nie jest załącznikiem do projektu planu wykładanego do publicznego wglądu i dyskusji ${ }^{42}$, a jest jedynie przedkładana radzie gminy, a więc traktowana jest jako dokument wewnętrzny. Mimo że odrębnego rozważenia wymaga kwestia, czy nie powinna być bezpośrednio przedmiotem debaty publicznej, to - jako że stanowi z pewnością informację publiczną i pełni funkcją informacyjną - jej dostępność powinna być na porównywalnym poziomie z projektem planu. Jednak ten zarzut należy kierować pod adresem prawo-

${ }^{42}$ Wyrok NSA z 23 stycznia 2013 r., II OSK 2348/12, orzeczenia.nsa.gov.pl. 
dawcy, gdyż brak przepisu, który by taki obowiązek nadkładał, nadto wskazuje się, że prognoza nie ma charakteru normatywnego, gdyż nie jest załącznikiem uchwały $^{43}$. Wydaje się, że nie jest to wyłącznie wewnętrzna sprawa gminy i jej potencjalnych zobowiązań finansowych, gdyż uchwalenie miejscowego planu może obciążać budżet gminy, co może się wiązać z podniesieniem opłat i podatków lokalnych. W orzecznictwie pojawił się pogląd, że nawet błędna prognoza finansowa, w szczególności błędne wyliczenie skutków finansowych dotyczących odszkodowań, nie stanowi kategorycznej przesłanki stwierdzenia z tego tytułu nieważności uchwały w sprawie miejscowego planu ${ }^{44}$. Niemniej pełni funkcję analizy ekonomicznej, która powinna być rzetelnie sporządzona i musi uwzględniać skutki, jakie powstaną w wyniku zastosowania dyspozycji m.in. art. 36 ustawy o planowaniu, a rada gminy powinna mieć świadomość, uchwalając plan miejscowy, o jego finansowych skutkach i powinna być to miarodajna informacja ekonomiczna. Zdaniem NSA istnieje możliwość podważenia uchwały przez wskazanie na zarzut istotnego naruszenia trybu sporządzania planu poprzez wadliwą prognozę skutków finansowych, ale trzeba by wykazać, że taka prognoza doprowadziła do uchwalenia planu, a gdyby była sumienna analizą ekonomiczna, do uchwalenia planu by nie doszło ${ }^{45}$. Niezależnie od powyższych tez należy podkreślić, że sprawy wielomilionowych odszkodowań, czy wykupu gruntów, to podstawowe kwestie związane z uchwaleniem planu, gdyż środki na ich wypłacanie znacząco obciążają budżety gmin ${ }^{46}$.

Kolejne zagadnienie, to lobbing, rozumiany jako narzędzie lub technika rzecznictwa interesów poprzez docieranie do decydentów ${ }^{47}$. Zainteresować i przekonywać do swoich racji należy z jednej strony organy jednostek pomocniczych. W dużych miastach najczęściej będą to rady osiedli, które zresztą w takim celu zostały utworzone. Na przykład § 9 pkt 1 pkt 11 uchwały nr LXXVI/1137/V/2010 Rady Miasta Poznania z 31 sierpnia 2010 r. w sprawie uchwalenia statutu Osiedla Umultowo stanowi, że Osiedle realizuje zadania m.in. poprzez wnioskowanie do organów Miasta o wywołanie lub zmianę miejscowego planu zagospodarowania przestrzennego na terenie Osiedla oraz o dokonanie zmiany w Studium uwarunkowań i kierunków zagospodarowania przestrzennego Miasta w części dotyczącej obszaru Osiedla, a pkt 7 umocowuje Radę Osiedla do opiniowania koncepcji projektów miejscowych planów zagospodarowania przestrzennego dotyczących obszaru Osiedla ${ }^{48}$. Bezpośredni kontakt z formalnie działającym organem może oznaczać podjęcie określonej uchwały

${ }^{43}$ Wyrok WSA w Rzeszowie z 29 października 2009 r., II SA/Rz 888/08, Lex, nr 576055.

${ }^{44}$ Wyrok WSA w Opolu z 14 czerwca 2012 r., II SA/Op 114/12, orzeczenia.nsa.gov.pl.

${ }^{45}$ Wyrok NSA z 23 stycznia 2013 r., II OSK 2348/12, orzeczenia.nsa.gov.pl.

${ }^{46} \mathrm{~Np}$. w Poznaniu Spółka Wyborowa w związku ze zmianą miejscowego planu oczekuje na wykup terenów przy ul. Komandoria na Maltą za kwotę $100 \mathrm{mln}$ zł, a roczna pula rezerwowana na takie cele to zaledwie kilkanaście milionów złotych, przy czym łączną kwotę takich roszczeń w Poznaniu szacuje się na ponad pół miliarda złotych, http://epoznan.pl/news-news-51492-Wyborowa_chce_od_miasta_wykupu_terenu_nad_Malta, czy http://epoznan.pl/news-news-48779-Decyzje_radnych_moga_kosztowac_Poznan_setki_milionow_zlotych (dostęp: 25.08.2014).

${ }^{47}$ K. Jasiecki, M. Molęda-Zdziech, U. Kurczewska (red.), Lobbing - sztuka skutecznego wywierania wptywu, Kraków 2006, s. 28.

${ }^{48}$ Zob. http://bip.poznan.pl/bip/uchwaly/uchwala-lxxvi-1137-v-2010-z-dnia-2010-08-31,35356/ (dostęp: 25.08.2014). 
i przekazanie jej do organów gminy. Z drugiej strony, często również za pośrednictwem rady osiedla skontaktować można się z radnymi reprezentującymi dany okręg. Ich stanowisko i ewentualne poparcie jest nie do przecenienia, gdyż to oni ostatecznie decydują o losie przeprowadzonego procesu planistycznego.

Wskazane powyżej ujęcie nieobligatoryjnych form konsultacji społecznych stanowi przed wszystkim analizę regulacji prawnej. Natomiast w ramach swojej samodzielności samorząd gminny może podejmować różnorodne działania w celu uspołecznienia procesów planowania przestrzennego, które nie sa wskazane wprost w ustawie o planowaniu przestrzennym. Do najczęściej wykorzystywanych form konsultacji zalicza się otwarte zebrania z mieszkańcami, badania ankietowe, konsultacje pisemne, sondaże internetowe, ale także różne formy warsztatów obywatelskich, jak np. zespoły planujące, grupy fokusowe i inne ${ }^{49}$. Jednym $\mathrm{z}$ rozwiąań może być tzw. model charette opracowany w Stanach Zjednoczonych, a upowszechniony w Europie ${ }^{50}$. Jego istota sprowadza się do konsultacji rozwiązań ze wszystkimi zainteresowanymi, a same konsultacje mają charakter interdyscyplinarny. Stąd biorą w nich udział urbaniści, architekci, specjaliści w dziedzinie transportu publicznego, mieszkańcy, deweloperzy, konserwatorzy zabytków i inne podmioty w zależności od charakterystyki i potrzeb danej przestrzeni. Uwzględnienie stanowisk wszystkich zainteresowanych może nawet doprowadzić do przyspieszenia uchwalenia miejscowych planów, lecz przede wszystkim zwiększa możliwość osiagnięcia trafnego rozstrzygnięcia. Wskazany model może być szczególnie cenny przy istotnych i dużych projektach, czy rozwiązywaniu konfliktów społecznych. Ze względu na wysokie koszty i stopnień złożoności dobrowolność decydowania o skorzystaniu z tej formy konsultacji byłaby zaletą.

Inne rozwiąaniem jest sondaż deliberatywny (deliberative polling) zastosowany w Polsce po raz pierwszy przy okazji debaty dotyczącej zagospodarowania stadionu modernizowanego w Poznaniu na EURO 2012 ${ }^{51}$. Ta metoda jest bardziej złożona, gdyż jest kilkuetapowa, nadto wymaga wyłonienia reprezentatywnej grupy obywateli posiadajaccej wiedzę umożliwiajaccą rozeznanie w danej sprawie. Rozpoczyna się od wstępnego, losowego badania ankietowego celem wybrania odpowiedniej grupy. Wyłonieni reprezentanci otrzymuja sporządzone przez ekspertów niezbędne materiały (napisane zrozumiałym językiem) wraz z kilkoma propozycjami rozwiąań. Następnie przeprowadza się cykl debat, wspólnie oraz w grupach prowadzonych przez moderatorów, i ponownie przeprowadza się ankietę. Dyskusja wraz z udziałem ekspertów i lokalnych władz trwa jeden lub kilka dni, a proces kończy jeszcze jeden sondaż, który w założeniu ma ukazać stanowiska reprezentantów uwzględniające poszerzoną wiedzę $e^{52}$.

${ }^{49}$ Zob. Ł. Młynarkiewicz, Regulacje samorzadowe oraz przyktady dobrych praktyk w obszarze konsultacji społecznych w Polsce i za granica, w: B. Dolnicki (red.), op. cit.

${ }^{50}$ M. Kruś, Warsztaty charette jako formuła rozstrzygania o warunkach zabudowy, „Studia Prawa Publicznego" 2013, nr 2, s. 177; B. Lennertz, A. Lutzenhiser, The Charrette Handbook, National Charrette Institute, Portland 2006.

${ }^{51}$ A. Przybylska, A. Siu, Co poznaniacy zrobia ze stadionem? Wyniki sondaży deliberatywnego w Poznaniu, Projekt Społeczny 2012, Warszawa 2012.

${ }^{52}$ Ł. Młynarkiewicz, Regulacje samorzqdowe oraz przyktady dobrych praktyk w obszarze konsultacji spotecznych $w$ Polsce $i$ za granica, w: B. Dolnicki (red.), op. cit. 
Kolejnym rozwiązaniem jest panel obywatelski stosowany z powodzeniem w Wielkiej Brytanii ${ }^{53}$. W odróżnieniu od powyższych metod jest to długotrwały proces, niekiedy wieloletni. Cykliczne badanie opinii wyłonionych losowo reprezentantów, przesyłane $\mathrm{w}$ dogodny dla nich sposób (droga pocztowa lub telefoniczna), ma na celu porównanie opinii tych samych osób i wskazanie ewolucji zmian. Co istotne, przy wykorzystaniu środków komunikacji elektronicznej przeprowadzenie panelu obywatelskiego nie musi być kosztowne.

Wszystkie powyższe propozycje łączy jedna wspólna myśl. Cel konsultacji jest ogólny - przedstawienie zarysu koncepcji, pomysłu, a nie nakłanianie do akceptacji gotowego projektu. Takie działania były już zauważone w teorii prawa i określane sa mianem tzw. argumentacyjnego sposobu stosowaniu prawa ${ }^{54}$. Proces grupowego planowania przez przedstawicieli wszystkich zainteresowanych stron wydaje się jedynym słusznym kierunkiem. Tym bardziej gdy rozstrzygnięcia nie zapadałyby $\mathrm{w}$ drodze głosowania, ale po osiagnięciu porozumienia.

\section{WNIOSKI}

K. Ostaszewski zauważa, że partycypacja w planowaniu przestrzennym jest współcześnie nie tylko postulatem, lecz powszechnie uznanym, niezbędnym elementem we wszystkich demokratycznych państwach ${ }^{55}$. Jednakże obowiązująca ustawa o planowaniu przestrzennym $\mathrm{w}$ niedostatecznym stopniu dopuszcza do współudziału członków społeczności lokalnych. Regulacja ustawowa w tym zakresie jest lakoniczna, co potęguje wrażenie, że uczestnictwo $\mathrm{w}$ debacie przestrzennej nie jest priorytetem. Można wręcz powiedzieć, że uprawnienia $\mathrm{w}$ zakresie podejmowania wiążących rozstrzygnięć są skumulowane w rękach organów administracji publicznej. Mimo istniejących wielostopniowych konsultacji społecznych ostateczne rozstrzygnięcie należy do organów gminy, gdyż z zasady wyrażane opinie, zgłaszane wnioski lub uwagi mają charakter niewiążący. Taka formuła umożliwia uchwalanie studium i miejscowych planów nawet wbrew woli mieszkańców gminy. Tym samym w odczuciu społecznym obecna procedura może być postrzegana jako narzucanie wizji ładu przestrzennego organu.

Trudno rozsądzić czy rozszerzenie zakresu uspołecznienia w procesach planistycznych należy rozpoczać od zmian ustawodawczych. Jest to ze swej istoty proces niełatwy i długotrwały, a ostateczny rezultat często jest wynikiem kompromisu, który może zniweczyć osiągnięcie zamierzonych celów. Odrębnej refleksji wymaga kwestia, w jakiej mierze uwzględnienie w większym stopniu

${ }^{53}$ Zob. P. Bednarz, Najlepsze praktyki w zakresie konsultacji spotecznych - Wielka Brytania, w: M. Bak, P. Kulawczuk, A. Szcześniak, Dobre rzadzenie poprzez wkład społeczny. Najlepsze praktyki prowadzenia konsultacji z organizacjami pozarzadowymi. Rekomendacje dla Polski, Warszawa 2011, s. 41-61.

${ }^{54}$ L. Morawski, Gtówne problemy wspótczesnej filozofii prawa, Warszawa 2000, s. 155.

${ }^{55}$ K. Ostaszewski, op. cit., s. 167. 
procedur partycypacyjnych wydłużyłoby czas uchwalania miejscowych planów. Stąd w obecnej chwili prościej jest wykorzystać potencjał tkwiący w konsultacjach nieobligatoryjnych. De facto oznacza to sięgnięcie do źródeł zasady pomocniczości i decentralizacji. Studium oraz miejscowe plany powstałe nie po zaopiniowaniu, ale w uzgodnieniu ze społecznościami lokalnymi, najlepiej z wykorzystaniem czynnika eksperckiego (urbaniści, architekci), w o wiele większym stopniu są $\mathrm{w}$ stanie rzeczywiście uwzględnić potrzeby i wnioski ogółu. Obiecującym rozwiązaniem jest uczestnictwo poprzez różnego rodzaju warsztaty. Zebranie wszystkich zainteresowanych w jednym miejscu i wspólne działanie celem wypracowania rozwiązania to ciekawa propozycja. Jasne i przejrzyste procedury przygotowywania i podejmowania rozstrzygnięć pozwalają uniknąć podejrzeń o partykularyzm, nepotyzm czy korupcję ${ }^{56}$ Im więcej będzie obserwatorów i uczestników procesów planistycznych, tym mniej pozostanie przestrzeni dla jednostkowych interesów. Nadto interesujacym rozwiązaniem sa długotrwałe (kilkumiesięczne, wieloletnie) procesy konsultacyjne. W takim przypadku można by łączyć je z konkursami architektoniczno-urbanistycznymi. Przy tym skorzystanie z określonej formy partycypacji zależeć powinno od konkretnej przestrzeni, jej specyfiki. Dlatego lepszym rozwiązaniem może być pozostawienie organom gminy swobody w wyborze formy.

Niezależenie od zastosowania konkretnego modelu warto w szerokim zakresie wykorzystać dostępne technologie informacyjne, w tym modele trójwymiarowe, a nawet gry, np. symulacyjne ${ }^{57}$. Skorzystanie z tych technik nie musi być kosztowne. Obecna regulacja prawna polega raczej na pasywnym dostarczaniu informacji przez organy gminy, nie umożliwia aktywnego wspomagania procesów decyzyjnych (tzw. partycypacja sieciowa), np. głosowanie online $^{58}$.

Resumując, skoro partycypacja służyć ma znajdowaniu powszechnie akceptowalnych rozwiązań, to w o wiele większym stopniu niż obecnie gminy powinny kształtować ład przestrzenny z uwzględnieniem procedur konsultacyjnych. Nawet jeśli nie zakończą się sukcesem, wypracowaniem konsensusu, to pozwolą na identyfikację problemów, a nadto pomogą zaktywizować społeczeństwo. Mimo że w Polsce nie ma długiej tradycji uczestniczenia w zarządzaniu sprawami publicznymi, to warto ją tworzyć i rozbudowywać. Odejść należy od modelu legitymizowania działań władzy na rzecz ciagłej współpracy ${ }^{59}$. Tylko wtedy można uzyskać ogólnospołeczny efekt.

dr Stawomir Pawtowski

Uniwersytet im. Adama Mickiewicza w Poznaniu

womir@amu.edu.pl

${ }^{56}$ D. R. Kijowski, op. cit., s. 11.

${ }^{57}$ Zob. M. Hanz, Technologie informacyjne jako narzędzie wspomagania debaty publicznej o kierunkach rozwoju, „Śląskie Studia Regionalne” 2011, nr 2,

${ }^{58}$ Tzw. model drabiny partycypacyjnej, zob. S. Arnstein, The Ladder of Citizen Participation, „Journal of Institute of American Planners” 35, 1969, nr 4, s. 216-240.

${ }_{59}$ M. Bożek, Konstytucyjne podstawy partycypacji społecznej $i$ formy jej realizacji $w$ samorzadzie terytorialnym, „Przegląd Sejmowy” 2012, z. 5, s. 107. 


\title{
OBLIGATORY AND FACULTATIVE CONSULTATIONS SET OUT \\ IN THE ACT ON PLANNING AND SPATIAL DEVELOPMENT AND THE EXTENT OF PARTICIPATORY SPATIAL DEVELOPMENT PROCESSES
}

\author{
Sum mary
}

The paper aims to present participation of local communities in the activities connected with local planning and spatial development. The analysis, predominantly focused on legal aspects, covers obligatory and facultative consultations and the extent of participatory planning processes. The non-binding character of the basic forms of asking inhabitants' opinions or receiving requests and complaints is most certainly inadequate to satisfactorily ensure local communities' participation in the shaping of the space or in the adoption of solutions aimed at creating a spatial order. The current solutions permit a practically unilateral, one-sided decision making when it comes to spatial planning and development. It is concluded that the potential underlying non-obligatory spatial consultations is not sufficiently used as social participation. Different possible forms of social participation such as open meetings with inhabitants, surveys and questionnaires, written consultations, web surveys or civil workshops, including planning teams, focus groups and others are not fully used or made advantage of. Their better use will be beneficial and contributory to social dialogues and the creation of a civil society, leading in consequence to the acceptance and of the adopted solutions and mitigation of the effects of potential conflicts. 
